\title{
INFORMATION TECHNOLOGY RESPONSES AND FINANCING ABILITY ON E-COMMERCE PERFORMANCE
}

\author{
Lis Sintha Ompusunggu 1 网 (iD, Ika Pratiwi Simbolon 2 四 \\ ${ }^{1}$ Universitas Kristen Indonesia, Jakarta, Indonesia \\ 2 Universitas Presiden, Cikarang, Indonesia
}

DOI: https://doi.org/10.29121/granthaalayah.v8.i9.2020.1584

Article Type: Research Article

Article Citation: Lis Sintha Ompusunggu, and Ika Pratiwi Simbolon. (2020). INFORMATION TECHNOLOGY RESPONSES AND FINANCING ABILITY ON ECOMMERCE PERFORMANCE. International Journal of Research GRANTHAALAYAH, 8(9), 328-333. https://doi.org/10.29121/granthaa layah.v8.i9.2020.1584

Received Date: 14 September 2020

Accepted Date: 30 September 2020

Keywords:

E-Commerce

Finance

Performance

Technology

\begin{abstract}
This research objective is to recalling the paradigm and describe the various responses to use information technology. This research is a type of literature study. This study is also descriptive research with the support of theories and the findings from previous studies. Responses to new technologies and financing ability play an essential role in achieving good performance. Strategic responses are different among firms that can be classified according to magnitude, domain, and speed. IT strategy, IT structure, social media and search engine marketing also other responses which have essential roles to the firm's performance.
\end{abstract}

\section{INTRODUCTION}

The information technology revolution affects the way of running a business to achieve a competitive advantage. With the development of that technology, companies need to use information technology to be able to compete with their competitors. Companies must abandon old methods and use new technology-based the Web context or more fully called the World Wide Web context [1]. The presence of e-commerce is creating significant changes to the operational activity of some business in creating value. Companies with e-commerce market orientation in generating business strategy will be more successful [2]. E-commerce development in Indonesia has tremendous growth in terms of web visitors in meeting their needs for daily basis. Here are the top 7 e-commerce in Indonesia: 
Source: iprice.co.id

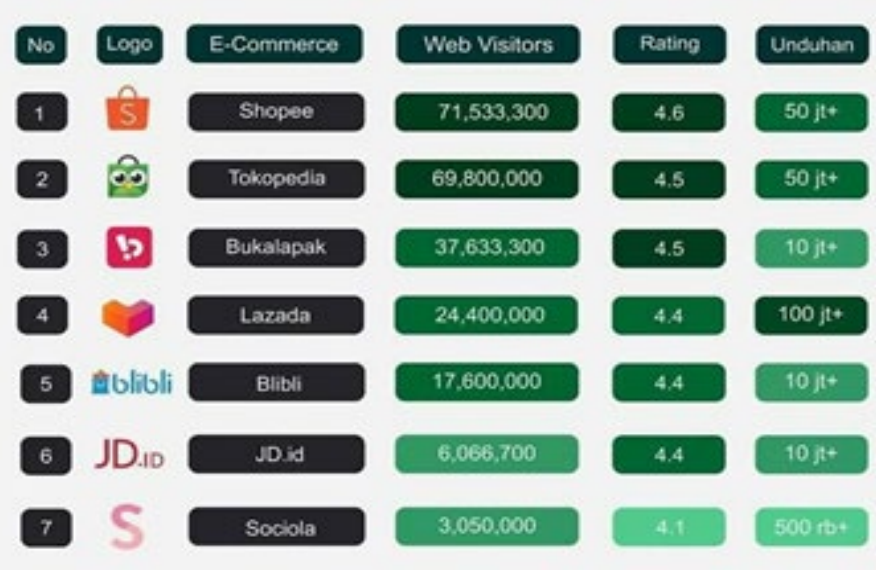

Figure 1: Top 7 E-Commerce in Indonesia

Due to the immediate needs of the community to fulfil their requirements by using information technology, companies should give different responses to technologies. It becomes essential to study the strategic responses roles in new technology on performance [3]. Responding to these technological developments, many companies use social media to do business daily to gain a competitive advantage. Companies can develop social networks, build the public page, and enhance online relationships [4], [5], [6]. Massive capital is necessary for technology innovation. Many e-commerce companies seek capital by using Initial Public Offering (IPO). Financing ability is defined as the ability to get capital. In general, companies can get funding through internal funding and external funding. The financing aspect can affect the performance of the company [7]. Strong support for working capital and firm performance [8]. Managers should avoid lost in sales or any additional financing expenses because it will lead to a negative effect on firm performance. Therefore, financing ability is essential in gaining a competitive advantage to compete with competitors.

This research makes several significant contributions to the development of theory and managerial activity in making the business strategy which in line with the development of information technology. This research highlights the findings and inventions from the previous research and describes the theory that has existed before.

\section{LITERATURE REVIEW}

Strategic responses for technology consist of the dimensions of magnitude, domain and speed [9]. Response magnitude is the firm's intensity in reacting to technology, whether accepting or ignoring the new technology. Response domain is related to the business process like supply chain management which is influenced by the latest technology [10]. Response domain is related to the routinity of firms [11], while response speed is related to the timeliness of the technology response [12]. Information technology strategy and structure are: a) Information technology strategy consists of environmental scanning and strategic use of information technology; b) Information technology structure consists of planning, control, acquisition and implementation of information technology [13].

Social media is one of the marketing tools that utilize information technology. Social media defines as a set of online and mobile environments focuses on interactivity, creating discussion of many people [14], [15]. Many studies have proven the critical role of social media as a trusted source of information than traditional communication tools [16]. Another technology approach is a search engine. The search engine is a powerful tool to support society to interact with others via online [17]. The search engine is defined as software in collecting data and information about certain websites [18].

Companies must consider the financing ability to run the business based on information technology. Financing ability defines as the ability to get funds, which is crucial for e-commerce growth [19]. In general, companies can get funding from external and internal financing. There are three internal sources of internal finance: sales of existing assets retained profits and cut down in stock levels. Meanwhile, external sources of finance are shares, venture capital, leasing, trade credit, etc. [20]. Innovation, mostly private companies, are constrained by internal funding [21]. Firms usually have a greater firm size from external funding [22]. 


\section{RESEARCH METHOD}

This research is a type of literature study. The analysis is using descriptive research with the support of theories and the findings from previous studies. Supported data is collected from online data, www.iprice.co.id; www.statista.com.

\section{RESULTS AND FINDINGS}

The dimensions of magnitude, domain, and speed - The strategic responses are related to magnitude, domain, and speed [3]. Greater magnitude can be illustrated from the application of the Internet as a sales channel. Different domains can be described through communication and sales channels in various business operational processes. In terms of speed, Lee and Grewal describe as the speed of communications, sales channel adoption and e-alliance formation. They examined nine years of data (1992 to 2000) for more than 100 companies for the effect of strategic responses on the performance of companies. In the findings of their research, they found that internet and e-alliance formation have a significant effect on the performance of companies. They found the response magnitude, domain and speed are needed to associate the technologies into business process appropriately. Retailers who assimilate the Internet in the business process generate higher performance compared to retailers who do not use the Internet in the business process.

Strategy and Structure of Information Technology - Chatzoglou studied the effect of information technology, structure of firms and strategic orientation on performance of firms. There must be an effect between the strategy of the business, the structure of business, strategy and structure of information technology [13]. IT strategy can be divided into environmental scanning and strategic use of information technology. IT can be divided into planning and control of information technology and acquisition and implementation of information technology. The managers need to select the appropriate type and level of IT to gain higher performance, depending on the structure of the company. They found that information technology has a substantial impact on performance when information technology, strategy and structure of a company are aligned together. It would give different result when these variables are considered independently. Understanding the importance of information technology, information system during the crisis by using survey data from Brazilian firms [23], [24]. They found that an information system can create strategies in response to environmental changes and gain better performance.

Social Media - Communication has been influenced massively by information technology. Social media is now accessible to be the platform for communication within one another for specific purposes. Figure 2 shows what platform is the most preferred by the public at this time. The development of social media is very rapid due to the increasingly high public needs for ease of meeting their daily needs. The Internet enables to reach a consumer that is not easily accessible, thereby making the creation of brand awareness easier [25]. Brand communication will increase through social media communication [26]. If the public already knows the brand quickly, it will lead to a better company's performance. Thus, they will easily compete with others because they assimilate the new technology in the business process.

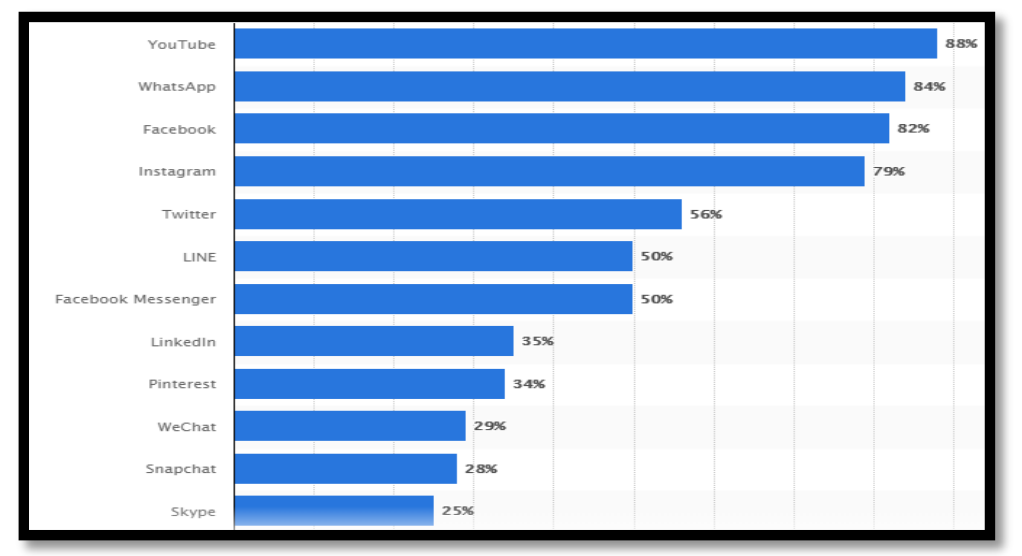

Figure 2: Leading Social Networks in Indonesia as of $3^{\text {rd }}$ Quarter 2019

Source: www.statista.com 
Tajvidi and Karami analyzed survey data by mail survey from 384 hotels in the UK. They found a positive and significant relationship between social media to firm performance [27]. Bhatti and Rehman examined the relationship between e-commerce on the performance of Pakistan's companies with the moderating role of social media. This study will help managers and new researcher to understand how e-commerce affects organization performance and social media moderate between them. They found that e-commerce significantly affects performance. Social media moderated between e-commerce and performance. Moreover, social media significantly affect performance.

Search Engine Marketing - Search engines become essential to increase the performance of small and mediumsized enterprises [28], [29], [30]. They extend business visibility by optimizing search engine. The firm, even the small one, can appear as well-known firms on search results by optimizing the search engine. They use multiple firms to examine how search engine impact website performances to achieve competitive advantage. Furthermore, The relationship of search engine marketing to performance on China's B2C e-commerce firms. Search engine marketing plays an important role as well as the business model to the performance of firms [31], [32]. The ability to get capital for e-commerce is crucial in generating good performance. Capital structure is also a critical factor in generating the firm's value that will lead to the sustainability of the company. The relationship between capital structure and performance in Ghana Stock Exchange of 22 companies [32], [33]. The investigation has been carried out from 1998 to 2002. Short term debt is less expensive than long term debt and generates higher performance. Total debt has a significant relationship to performance, which indicates that the increasing level of debt will lead to an increased level of performance.

The financing ability harms the performance of firms. Low returns indicate that the concentration of managers is on innovation and relationship management of the customer. Financing ability increases during revenue decreases because capital is used for extended reproduction. Furthermore, Yang, Xia and Wen examined the relationship among venture capital [34], [35], [36], [37] financial leverage and performance in China's Growth Enterprises for the period 2010 to 2014 . They found that venture capital is significantly related to the performance of corporate, and financial leverage is significantly correlated with the performance of corporate.

\section{CONCLUSION}

This study will help managers and new researcher to understand how information technology and financing ability affect the performance of companies. The adoptions of the Internet to communicate with all of the shareholders and e-alliance significantly affect the performance of companies. Managers should select the appropriate type and level of information technology in order to gain benefit from information technology.

\section{SOURCES OF FUNDING}

This research received no specific grant from any funding agency in the public, commercial, or not-for-profit sectors.

\section{CONFLICT OF INTEREST}

The author have declared that no competing interests exist.

\section{ACKNOWLEDGMENT}

None.

\section{REFERENCES}

[1] Parandeh (2000). in e-commerce, printing, publishing, Business Office, Journal of Cooperatives.

[2] Chang, K. C., Jackson, J. Grover, V., 2003. E-commerce and corporate strategy: an organizational perspective. Information \& Management. 40, 663-675.

[3] Lee, R. P., Grewal, R., 2004.Strategic Responses to New Technologies and Their Impact on Firm Performance. Journal of Marketing. 
Information Technology Responses and Financing Ability on E-Commerce Performance

[4] Bhatti, A. (2018). Factors Affecting Consumer Purchase Intention with the Mediating Role of Corporate Social Responsibility in Pakistan. International Journal of Academic Management Science Research, 2(8).

[5] Bhatti, A., \& Maraim, S. A. (2017). The Impact of Social Media Mobile Advertising on Consumer Perception and Consumer Motivation by Considering Mediating Role as Brand Image and Brand Equity. Message from the Founder of Pakistan, 376.

[6] Velez, I. S., \& Vasquez, L. M. G. (2011). Social Media as a strategic tool for Corporate

[7] Chang, S. J. (2004). Venture Capital Financing, Strategic Alliances, and the Initial Public Offerings of Internet Startups. Journal of Business Venturing, 19.

[8] Caballero, S. B., Teruel, P. J. G., Solano, P. M. (2014). Working Capital Management, Corporate Performance, and Financial Constraints. Journal of Business Research. 67, 332-338.

[9] Heil, Oliver and Thomas S. Robertson (1991). Toward a Theory of Competitive Marketing Signaling: A Research Agenda. Strategic Management Journal, 2(6), 403-418.

[10] Srivastava, Rajendra K., Tasadduq A. Shervani, and Liam Fahey (1999). Marketing, Business Processes, and Shareholder Value: An Organizationally Embedded View of Marketing Activities and the Discipline of Marketing. Journal of Marketing, 63 (Special Issue), 168-79.

[11] Nelson, Richard R. and Sidney G. Winter (1982). An Evolutionary Theory of Economic Change. Cambridge, MA: The Belknap Press.

[12] Lieberman, Marvin B. and David B. Montgomery (1988). First Mover Advantages. Strategic Management Journal, 9 (Summer Special Issue), 41-58.

[13] Bergeron, F., Raymond, L., \& Rivard, S. (2004). Ideal patterns of strategic alignment and business performance. Information \& management, 41(8), 1003-1020.

[14] Porter, C. E., Donthu, N., MacElroy, W. H., and Wydra D. (2011). How to foster and sustain engagement in virtual communities. California Management Review, 53(4), 80- 110.

[15] Kietzmann, J. H., Hermkens, K., McCarthy, I. P., and Silvestre, B. S. (2011). Social media? Get serious! Understanding the Functional Building Blocks of Social Media. Business Horizons 54, 241-251.

[16] Karakaya, F. \& Barnes, N. G. (2010) Impact of online reviews of customer care experience on brand or company selection. Journal of Consumer Marketing. 27(5), 447-457.

[17] Liaw, S. S., \& Huang, H. M. (2006). Information Retrieval From the World Wide Web: A user-focused Approach Based on Individual Experience with Search Engines. Computers in Human Behavior, 22(3), 501-517.

[18] Yalçin, N., and Köse, U. (2010). What is Search Engine Optimization: SEO?. Procedia - Social and Behavioral Sciences. 9.

[19] Yang, Z., Shi, Y., and Wang, B. (2015). Search Engine Marketing, Financing Ability and Firm Performance in Ecommerce. Procedia Computer Science. 55, 1106 - 1112

[20] Rossi, M., Lombardi, R., Siggia, D., and Oliva, N. (2015). The Impact of Corporate Characteristics on the Financial Decisions of Companies: Evidence on Funding Decisions by Italian SMEs. Journal of Innovation and Entrepreneurship. 2.

[21] Guariglia, A., Liu, P. (2014). To what extent do financing constraints affect Chinese firms' innovation activities?. International Review of Financial Analysis, 36, 223-240.

[22] Colombo, M. G., and Grilli, L. (2005). Start-up Size: The Role of External Financing. Economics Letters, 88(2).

[23] Yoshikuni, A. C., and Albertin, A. L. (2018). Effects of strategic information systems on competitive strategy and performance. International Journal of Productivity and Performance Management. 67(9), 2018-2045.

[24] Tyas, E. H., \& Naibaho, L. (2019, November). The urgency of entrepreneurship learning in the industrial age of 4.0. In Journal of Physics: Conference Series (Vol. 1387, No. 1, p. 012032). IOP Publishing.

[25] Keller, K.L. (2009). Building Strong Brands in a Modern Marketing Communications Environment. Journal of Marketing Communications, 15(2/3), 139 - 155.

[26] Smith, A. N., Fischer, E. \& Yongjian, C. (2012). How Does Brand-related User-generated Content Differ across YouTube, Facebook, and Twitter? Journal of Interactive Marketing, 26(2), 102-113. Direct Marketing Educational Foundation, Inc.

[27] Bhatti, A., Rehman, S. U. (2019). E-Commerce Effect on Organization Performance with the Moderating Role of Social Media. International Journal of Business Management. 4(1), 1-8.

[28] Nadeak, B., Naibaho, L., \& Silalahi, M. (2020). COVID-19 and Students' Anxiety Management. International Journal of Innovation, Creativity and Change, 13(7), 1574-1587. 
[29] Tomasi, T., Li, X. 2015. and The Impact Of Search Engine Optimization on Website and Business Performances of Small and Medium-Sized Enterprises. Journal of Electronic Commerce in Organizations. 13(1), 27-49.

[30] Nadeak, B., \& Naibaho, L. (2019, November). Investigating the effect of learning multimedia and thinking style preference on learning achievement on anatomy at Universitas Kristen Indonesia. In Journal of Physics: Conference Series (Vol. 1387, No. 1, p. 012116). IOP Publishing.

[31] Yang, R., Xia, K., and Wen, H. (2016). Venture Capital, Financial Leverage and Enterprise Performance. Procedia Computer Science. 91, 114 - 121.

[32] Naibaho, L. (2014). The Role of Education and Culture in the Development of Character and Civilization of the Plural Indonesian Nation. Jurnal the Ary Suta Center Series on Strategic Management, 27(0), 69.

[33] Tyas, E. H., \& Sunarto, L. N. (2020). Building Superior Human Resources through Character Education.

[34] Sintha, L. (2019). Model Earning Dalam Prediksi Kepailitan Bank. Journal of Banking and Finance, 1(1), 1-9.

[35] Tyas, E. H., \& Naibaho, L. (2020). Building A Culture of Tolerance Since Early Childhood. International Journal of Research-GRANTHAALAYAH, 8(8), 244-249.

[36] Sintha, L. (2020). Importance of Break-Even Analysis for the Micro, Small and Medium Enterprises. International Journal of Research-Granthaalayah, 8(6).

[37] Abor, J. (2005). The Effect of Capital Structure on Profitability: an Empirical Analysis of Listed Firms in Ghana. Journal of Risk Finance. 6, 438-47. 